\title{
SUSTAINABILITY RESEARCH IMPLEMENTATION IN PRODUCT DEVELOPMENT - LEARNINGS FROM A LONGITUDINAL STUDY
}

\author{
Hallstedt, Sophie I. (1); Nylander, Johanna W. (2) \\ 1: Blekinge Institute of Technology, Sweden; 2: GKN Aerospace Engine System, Sweden
}

\begin{abstract}
Industry is a main stakeholder when it comes to realising the transition towards a sustainable future. Academia, with its, knowledge and methods, needs to support the industry on this journey. This paper, focuses on the practical learnings on how to implement sustainability research from an industrial perspective. It aims to share some lessons learnt from a longitudinal case study and a development journey in implementing sustainability research in the product innovation process at GKN Aerospace Engine System. The paper gives an overview, based on a literature study, of what is required to successfully implement sustainability in product development. It also provides a summary of the different research projects at the company with learnings from practical and academic perspectives, and the main learnings and changes in relation to different development phases in the sustainability journey. Although, this journey began over ten years ago, and shows the importance of long-term collaboration, it provides key-factors that can be applied also in short term collaborations and for faster implementation of research in general and sustainable product development research in particular.
\end{abstract}

Keywords: Sustainability, Longitudinal study, Case study, Integrated product development, Implement

Contact:

Hallstedt, Sophie

Blekinge Institute of Technology

Department of Strategic Sustainable Development

Sweden

sophie.hallstedt@bth.se

Cite this article: Hallstedt, S.I., Nylander, J.W. (2019) 'Sustainability Research Implementation in Product Development - Learnings from a Longitudinal Study', in Proceedings of the 22nd International Conference on Engineering Design (ICED19), Delft, The Netherlands, 5-8 August 2019. DOI:10.1017/dsi.2019.345 


\section{INTRODUCTION}

There is an increased awareness of the value of university-industry collaboration (Borrell-Damian, 2009). This regards both quality of research and the implementation of research. Close and long-term collaboration projects, e.g. industrial $\mathrm{PhD}$ programmes have been successful. However, bridging the gap between university and industry can be difficult, due to different contextual backgrounds (Wallin et al, 2014). Regarding sustainability, the university-industry collaboration has become even more important due to the climate change and other sustainability challenges that threaten the global natural systems (IPCC, 2018; Steffen et al., 2015). Industry is a main stakeholder when it comes to realising the transition towards a sustainable future. Academia, with its resources, knowledge and methods, needs to support the industry on this journey. The main contribution of this paper is to share some practical learnings on how to implement sustainability research from an industrial perspective.

The knowledge of academia can be transferred to the industry through a variety of channels (Agrawal, 2001) and the most common channel is the education of students that get employed by the industry. However, this channel is a long-term process and too slow if the purpose is to include a sustainability thinking in the organisation in near time, with the aim to transfer society to attain a more sustainable world. In parallel to new recruitments, integration of new methods can be a more efficient and faster way to change daily practices (Beckmann et al., 2016). However, knowledge transfer through new methods and tools also has many challenges such as methods that are poorly built on prior research or empirical studies; that do not meet the needs of engineers or industry, and that are too complex, inflexible and theoretical (Blessing and Chakrabarti, 2009; Wallace, 2011). In Beckmann et al. (2016), success factors for methods transfer and a methodological approach for the methods transfer have therefore been developed. The success factors identified in that study were the following: understand the company needs, adapted and simple methods, training and provision of support, top management support, mediate and quantify benefits, convincing and involvement of people, pilot projects and examples, anchoring in the organisation, improve method regularly, planning and management, and method experts. Method experts are also considered to be one of the most important missing links according to Wallace (2011). He means that there is, generally, nobody assigned to transfer design methods into practice. Also, to have a person assigned as responsible for sustainability implementation, including methods in the product innovation process, is pointed out as one of the key elements by Hallstedt et al. (2013a). Other key elements for successfully implementing a strategic sustainability perspective into the early stages of the product innovation process are the following: ensure organisational support from senior management; efficiently introduce a sustainability perspective early in the product innovation process; utilize knowledge and experience of procurement staff in the earliest phases of the process; include social aspects across the product life cycle and its value chain; have a systematic way for knowledge sharing and competence building in the sustainability field to inform decisions taken in future product development projects; utilize tools for guiding decisions as a complement for assessment tools, and utilize tools that incorporate a backcasting perspective.

This paper, however, does not focus on the theoretical view on how to implement sustainability in the industry, but on the practical learnings on how to implement sustainability research from an industrial perspective. The paper aims to share lessons learnt from a longitudinal case study and a development journey in implementing sustainability research in the product innovation process at GKN Aerospace Engine System, which is a large first-tier supplier of aero-engine components. Although this journey began over ten years ago, and demonstrates the importance of long-term collaboration, the paper also provides keyfactors that can be applied also in short term collaborations and for faster implementation. The purpose is therefore also to identify key factors for implementing sustainability research from academia into practical product development in industry.

Based on the above, the research question in this study is: What are the key factors for successful implementation of sustainability research in the product innovation process?

In the following section 2, the research methods are presented. Section 3 contains the results from the literature study, including an overview of what is required to successfully implement sustainability in product development, together with suggestions for future research and development tracks. A summary of the different research projects at the company with learnings from both practical and academic perspectives is presented in chapter 4 . This is, in section 5, followed by an excerpt of the main learnings and changes in relation to the different development phases that GKN has passed through to become more systematic in its 
sustainability journey. Finally, section 6 concludes by reflecting on the value and contribution of the learnings from the development journey in implementing sustainability research. In addition, key factors for implementing research and in particular sustainability research from academia into practical product development in the industry is presented.

\section{METHODS}

This paper is based on a longitudinal case study (Åhlström and Karlsson, 2009) with focus on one company, GKN Aerospace Engine System, and its sustainability journey that we have followed and been part of for over 10 years. The company finds itself within a conservative industry due to its regulations and long-term development processes, and it is also a large company. This context makes it difficult for easy transformation of changes. However, slow but systematic changes have been made and documented during the years.

This paper shows an overview of the sustainability journey in retrospect and some step-by-step progression of how academic results within the field of sustainability in design have been implemented in practise. Several different projects with the company involved have been compiled into a table, see Table 1, and sorted by time period including the purpose of the project, funders, and main academic contributions. The learnings are gathered and summarized in section 5 .

A systematic literature review was planned and developed to give an overview of previous research regarding sustainability implementation in product development. The literature review followed the guidance of the research methodology proposed by Blessing and Chakrabarti (2009). First, an initial review on sustainability implementation was performed to identify key words. From the initial review, combined keywords with relevant Boolean operators were used, for example: (sustainab* AND implement* AND "method OR tool"); (Sustainab* AND implement* AND "Product process"), and (sustainab* AND implement* AND "product development" OR "product design" AND integration). The search was limited to journal papers, book chapters and conference proceedings written in English and published after 1999, using the database SCOPUS. A brief title and abstract screening was made filtering the search results from 169 to 34 papers. The selection process started by reading the titles of the 169 papers in the selected database. Dependent on the degree of relevance, abstract and key words were read. At this stage, around 34 papers were explored further by reading their introduction and conclusions. Based on an assessment of the articles' relevance in relation to sustainability implementation in product design, the following 14 papers were identified for full review, also including the applied method, purpose and results: Ahmad et al. (2017); Alblas et al. (2014); Chiu and Chu (2012); Choi et al. (2008); Hallstedt et al. (2013a); Hassan et al. (2014); Held et al. (2018); Kara et al. (2014); Kishawy et al. (2018); Lermen et al. (2018); Mourtzis et al. (2018); Rodrigues et al. (2017); Rodrigues et al. (2018); Short et al. (2012). Conventional qualitative content analysis (Hsieh and Shannon, 2005) was deployed and key attributes of each source were documented.

\section{IMPLEMENTING SUSTAINABILITY IN PRODUCT DEVELOPMENT- OVERVIEW FROM LITERATURE REVIEW}

Integrating the breadth of sustainability into product development is labelled sustainable product development (SPD) or sustainable design (Gagnon et al., 2012). Sustainable product development means here that a strategic sustainability perspective is integrated and implemented into the early phases of the product innovation process, including life-cycle thinking (Hallstedt and Isaksson, 2017).

Sustainability implementation refers to the practical usage and application of tools, methods, processes, approaches, practices, etc., that aim to improve an organization's contribution to sustainable development. To implement sustainability in the early stages of the product innovation process, i.e., in the design stages, means to provide opportunities for improving environmental aspects of a product and for enhancing the product competitiveness. (Chiu and Chu, 2012; Choi et al., 2008). An important means for implementation is to use decision support (Hallstedt et al., 2010) and there is a wide range of sustainability-oriented methods and tools (SPD tools) for decision support in product development (Bovea et al., 2012; Buchert et al., 2014; Chiu and Chu, 2012). Most SPD tools designed to support sustainability considerations in the product innovation process have, however, a low level of practical applicability (Zetterlund, 2016; Held et al., 2018). To enhance acceptance and practical usage in the industry, future research directions were suggested by Ahmad et al. (2018) based on a recent review of sustainable product design tools and their applications. One 
area to focus on is the challenges and practical usage associated with support tools. Support tools need to be improved regarding the maturity level, as well as of meeting the desired characteristics, e.g., easy to use, resource and time efficient, and provide guidance to make sustainability improvements. Moreover, future research may focus on the development of standard indicators, measurement procedures, measurement units and weighing of sustainability indicators for different design problems. Another area of future research focus is the adoption of SPD tools for software or computer-based systems to increase their usability in industries. Further on, Ahmad et al. (2018) state that an important research direction to improve SPD tools and their performance is to combine and apply simulation-driven and stochastic approaches to deal with uncertainties. Finally, the study concludes that a strong collaboration between academic researchers and industrial practitioners is required to increase the practical application and usage of tools in industry.

The success for implementing sustainability in product development is not only dependent on practical application of SPD tools. Other success factors are corporate strategy and management support with central responsibility and high awareness in the company (Held et al., 2018 and Schulte and Hallstedt, 2018b). A clear scope and concrete sustainability targets are also needed for the management to be able to justify company investments of sustainability initiatives and to make progression (Alblas et al., 2014). Further on, Alblas et al. (2014) state that proactively managing sustainability in product development requires some innovative and entrepreneurial skills as manufacturers need to accept some uncertainty and work with incomplete information when integrating sustainability in the early product design stages. Supportive knowledge from the academia to the industry is needed to help companies to understand and set a scope for sustainability (Alblas et al., 2014). To have a better understanding in the industry of the importance of sustainability implementation and how to make a change whilst minimizing risk is required to be successful in sustainable product development (Short et al., 2012).

\section{SUSTAINABLE PRODUCT DEVELOPMENT RESEARCH PROJECTS}

Table 1 gives an overview of the research projects conducted between the academic partner and the industrial partner in the field of SPD. The SPD research in these projects include the three dimensions of sustainability, i.e. social, ecological and economic, and is based on the Framework for Strategic Sustainable Development (FSSD), including the definition of socio-ecological sustainability using overarching sustainability principles at the basis of a backcasting perspective (Broman and Robèrt, 2017). Continuous research and industrial collaboration has taken place over a period of 12 years. Many of the projects have had several industrial partners involved, with many case studies and different activities. The projects have not only had academic results as targets but have also aimed to provide a learning and sharing platform between all the partners. During the years and after some projects the collaboration and co-production increased gradually. The research has been characterised by action research (Avison et al., 1999), including several interactive activities involving researchers and practitioners. The action research activities included problem diagnosis, action intervention and reflective learning according to Couglian and Coghlan (2009). Empirical and qualitative data has been collected through the authors' active participation and the applying of data triangulation, as described in O'Donoghue and Punch (2003). This meant that the collected data and information was crosschecked by using multiple sources to search for regularities and certainty in the data collection. Over the years more advanced collaboration activities were accomplished by practitioners and researchers, such as, application of tools, training of company employees, co-development of support tools, meaning that the company activities, gradually, were more in line with the project focus and the academic problems that needed solving.

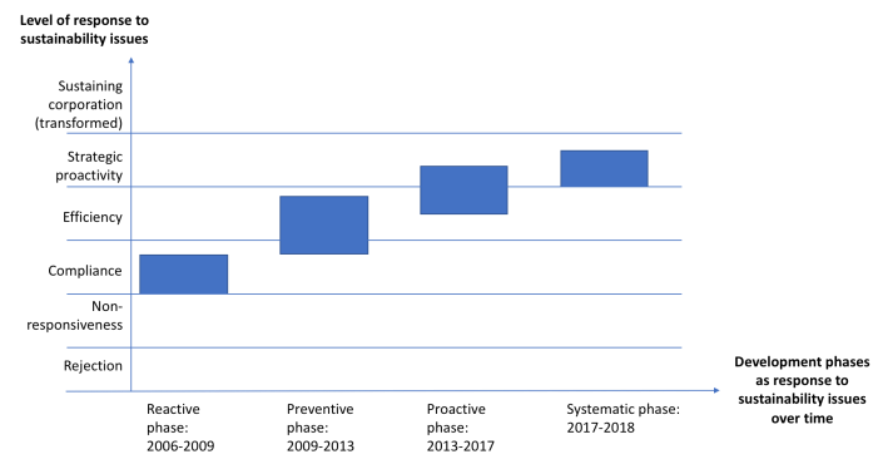

Figure 1. The company's development versus level of response to sustainability issues. 
Table 1. Overview of the research-industry collaboration projects in the field of sustainable product development during the years of 2006-2018.

\begin{tabular}{|c|c|c|}
\hline $\begin{array}{l}\text { Time period: Project } \\
\text { title/Funders }\end{array}$ & $\begin{array}{l}\text { Main activities at the company/Main contribution } \\
\text { at the company }\end{array}$ & Main academic contribution \\
\hline $\begin{array}{l}\text { 2006-2009: Prioritisation } \\
\text { Support for SPD/ } \\
\text { Knowledge Foundation } \\
\text { (KKS), Blekinge Institute } \\
\text { of Technology (BTH) and } \\
\text { Industry }\end{array}$ & $\begin{array}{l}\text { Investigated the current level of sustainability } \\
\text { integration in the product innovation process. / An } \\
\text { understanding of current challenges and } \\
\text { possibilities for a strategic sustainability } \\
\text { perspective in their product development } \\
\text { innovation process. }\end{array}$ & $\begin{array}{l}\text { An approach to assessing sustainability } \\
\text { integration in strategic decision } \\
\text { systems. Hallstedt et al. (2010) } \\
\text { Key Elements for Implementing a } \\
\text { Strategic Sustainability Perspective in } \\
\text { the Product Innovation Process. } \\
\text { Hallstedt et al. (2013) }\end{array}$ \\
\hline $\begin{array}{l}\text { 2009-2011: } \\
\text { Post-doc for Sustainable } \\
\text { Product Innovation/ KKS } \\
\text { and Volvo Aero }\end{array}$ & $\begin{array}{l}\text { Application of a new SPD method including a } \\
\text { strategic sustainability assessment and simplified } \\
\text { life-cycle assessment. / A major change of a design } \\
\text { decision, based on the findings from the SPD } \\
\text { method, regarding a manufacturing process. }\end{array}$ & $\begin{array}{l}\text { Assessing sustainability and value of } \\
\text { manufacturing processes: a case in the } \\
\text { aerospace industry. Hallstedt et al. } \\
\text { (2015) }\end{array}$ \\
\hline $\begin{array}{l}\text { 2010-2013: } \\
\text { Decision support for } \\
\text { sustainable Value Chains/ } \\
\text { KKS, BTH and Industry }\end{array}$ & $\begin{array}{l}\text { Workshop activities with actors in the value chain } \\
\text { to identify future challenges in the life cycle. } \\
\text { Material criticality assessment (MCA) method was } \\
\text { developed from participation action research. /The } \\
\text { MCA method was implemented in the company's } \\
\text { Technology Readiness Assessment method to } \\
\text { support material selection in early design stages. }\end{array}$ & $\begin{array}{l}\text { Material criticality assessment in early } \\
\text { sustainable product development. } \\
\text { Hallstedt and Isaksson (2017) }\end{array}$ \\
\hline $\begin{array}{l}\text { 2011-2013: } \\
\text { Sustainability criteria in } \\
\text { concept evaluation } \\
\text { methodology/ Vinnova, } \\
\text { BTH and Volvo Aero }\end{array}$ & $\begin{array}{l}\text { Investigations of current measures to integrate } \\
\text { sustainability in the product innovation process. } \\
\text { Training sessions at the company. / A sustainability } \\
\text { design space to give guidance of the most } \\
\text { important sustainability criteria identified for the } \\
\text { company, to be integrated in the Technology } \\
\text { Readiness Assessment method. }\end{array}$ & $\begin{array}{l}\text { Sustainability Criteria and Sustainability } \\
\text { Compliance Index for Decision Support } \\
\text { in Product Development, (Hallstedt, } \\
\text { 2017) }\end{array}$ \\
\hline $\begin{array}{l}\text { 2013-2019: } \\
\text { Model Driven } \\
\text { Development and } \\
\text { Decision Support/ KKS, } \\
\text { BTH and Industry }\end{array}$ & $\begin{array}{l}\text { In co-production mode developed a user-friendly } \\
\text { support method for sustainable product-service } \\
\text { system innovations. / A first prototype of a model- } \\
\text { based decision support for value and sustainability } \\
\text { assessments was integrated with the company's } \\
\text { engineering models. }\end{array}$ & $\begin{array}{l}\text { Model-based decision support for } \\
\text { value and sustainability assessment: } \\
\text { applying machine learning. Isaksson et } \\
\text { al. (2015), Bertoni, et al. (2018) }\end{array}$ \\
\hline $\begin{array}{l}\text { 2015-2018: } \\
\text { Strategic, Tactical and } \\
\text { Operational } \\
\text { implementation of } \\
\text { Sustainability into the } \\
\text { Innovation Process/ KKS, } \\
\text { BTH and Industry }\end{array}$ & $\begin{array}{l}\text { Close collaboration and co-production, including } \\
\text { training sessions together with workshops } \\
\text { activities, between academia and practitioners for } \\
\text { how to implement SPD. / Better understanding of } \\
\text { how to integrate and implement sustainability on } \\
\text { different levels in the company to add value and } \\
\text { avoid risks. }\end{array}$ & $\begin{array}{l}\text { Company Risk Management and } \\
\text { Sustainability. Schulte and Hallstedt } \\
\text { (2018a) } \\
\text { Sustainability product portfolio. Villamil } \\
\text { and Hallstedt (2018) } \\
\text { Sustainability in product requirements. } \\
\text { Watz and Hallstedt (2018) } \\
\end{array}$ \\
\hline $\begin{array}{l}\text { 2018: } \\
\text { Sustainability } \\
\text { Implementation Package } \\
\text { - SIP step 1/Vinnova, } \\
\text { BTH, and Industry }\end{array}$ & $\begin{array}{l}\text { Workshops, discussions, and in-depth } \\
\text { investigations together with researchers. / } \\
\text { Together with researchers created a base for } \\
\text { developing a digitalized implementation package } \\
\text { with methodology and interconnected methods } \\
\text { and tools to systematically integrate and } \\
\text { implement sustainability in product development } \\
\text { process. }\end{array}$ & $\begin{array}{l}\text { Preconditions to build capabilities for } \\
\text { sustainable product design and a self- } \\
\text { assessment method for sustainability } \\
\text { implementation in product } \\
\text { innovation. Schulte and Hallstedt } \\
\text { (2018b) }\end{array}$ \\
\hline
\end{tabular}

Parallel to the above mentioned research projects, there have been other projects at the company related to ecological sustainability, for example, the European Union funded projects Clean Sky (1 and 2) with the aim to reduce $\mathrm{CO} 2$ emission from the aerospace industry, and technology development projects with the focus on sustainable manufacturing. 


\section{MAIN LEARNINGS AND PHASES DURING THE SUSTAINABILITY IMPLEMENTATION JOURNEY}

GKN Aerospace Sweden has in over a decade carried out a close collaboration with the academic partner Blekinge Institute of Technology regarding sustainability in the product innovation process. During this period certain activities have been continuous, such as the mapping of the sustainability work in the company. Since nothing remains the same and everything continues to evolve, it is and must be a continuous work. Apart from the mapping of the sustainability work in the company, it has been clear that the company has gone through certain phases, here referred to as reactive, preventative, proactive and systematic, in its sustainability journey. These phases can be related to the six levels of response to sustainability issues described by Dunphy et al. (2007), i.e., rejection, non-responsiveness, compliance, efficiency, strategic proactivity and the sustaining (transformed) corporation. GKN had already passed the first two levels, i.e., rejection and non-responsiveness, when the collaboration started. During the twelve years of collaboration, GKN has gone through the levels of compliance, efficiency, and strategic proactivity (Figure 1). To shift to the sixth level, i.e., the transformed one, a broader societal transformation is required, according to Gaziulusoya et al., (2013).

The development phases at GKN were as follows:

I) Reactive phase, corresponding to the compliance level. During this time period, 2006-2009, chemicals used in production phases and in product material were in focus due to customer request and legislation. The focus was on environmental issues and how to comply with environmental legislations. The environmental improvements were still viewed as a cost. During this time the research regarding the understanding of sustainable product development raised the sustainability awareness among technology-and development teams at the company and gradually the company moved to the preventative phase.

II) Preventive phase, corresponding to the efficiency level. During this time period, 2009 - 2013, the industry focus was on a reduction of costs and to improve the corporate image. A simplified life-cycle assessment (developed in research project) was frequently applied during this period. However, it was optional for projects to do this life-cycle assessment. So, when the expert of the support tool left the company it was not used regularly anymore. Regular assessments regarding "substances of very high concern" were instead systematically conducted at the company in line with the regulation concerning the Registration, Evaluation, Authorization and Restriction of Chemicals (REACH). These reactive approaches were first done to fill customer needs or legislations. But during this period, the sustainability research created an increased awareness of a need for both a short- and long-term sustainability perspective in decision making, to get tactical-and strategic business advantages. This was seen as particular important for the company due to its high performance products having a life cycle of many decades. The product design team started to understand the implications from a sustainability perspective when making selections already in the design phase. Based on that understanding, a need for a simple but relevant tool was asked for. Scenario building including actors in the value chain to support decision making (Hallstedt et al., 2013b) was introducing thoughts to a new decision support tool, the Sustainability Assessment and Value Evaluation (Hallstedt et al., 2015).The company had now a more proactive thinking when taking decisions in the product innovation process.

III) Proactive phase, corresponding to the strategic proactivity level. During this time period, 2013 2017, a sustainability design space was defined in research collaboration (Hallstedt, 2017). This made the life-cycle thinking more obvious in the product design team as they realised their responsibility from selecting materials, and manufacturing processes provided by stakeholders up-stream in the value chain. Based on the defined sustainability design space, the research showed that one of the most important sustainability aspects to consider during the early phases of the product innovation process was the content of critical materials in alloys, i.e., critical from an availability and sustainability perspective. The company started to do systematic assessments related to conflict-free sourcing, with the purpose to eliminate conflict materials in the alloys. The company's purpose with this proactive approach was to be prepared and be able to systematically avoid potential future problems on a long-term basis. The focus was therefore on a combined view of availability as well as on social and ecological issues. A new material criticality assessment method (Hallstedt and Isaksson, 2017) was then developed in participation action research with the academic partner. It was intended to be used as decision support in early product development for the company as well as for other companies in the same or similar 
industry sectors. A systematic approach was now needed to ensure a recurring proactive approach in the daily engineering environment.

IV) Systematic phase, also corresponding to the strategic proactivity level. During this time period, 2017 - present time, a systematic process to integrate the sustainability perspective in the company's technology readiness level assessment method started to develop, to avoid the risk of suboptimisations in form of unintended consequences. This included the sustainability design space and the developed support tools from the research team, such as the material criticality assessment method. The sustainability process in the technology readiness level assessment method was later converted into an instruction for how to do the sustainability assessments at the company, including an updated life-cycle assessment tool that is company specific. The current strategy is to make sustainability assessments mandatory for all product and technology development projects. In addition, continuous work to follow up on the progression in implementing sustainability is conducted on a tactical and systematic level using a self-assessment method (Schulte and Hallstedt 2018b). Recurring usage of this method has visualized and emphasized the progress in the company's sustainability journey.

Sustainability has become a more central role in the company vision and management team during these years. The awareness regarding sustainable product development in the company has risen to a higher level after a sustainability prize was awarded to GKN from one of their most important customers. But the sustainability journey is by no means finished. Several research approaches are currently taken place simultaneously, not necessarily focusing on developing a new tool but rather on how sustainability can be integrated and combined with current processes, tools and systems, e.g., in the product portfolio development (Villamil and Hallstedt, 2018), product requirement management (Watz and Hallstedt, 2018), risk management system (Schulte and Hallstedt, 2018a) and in a company-specific advanced engineering support tool for concept generation, evaluation and optimisation (Bertoni et al., 2018).

From this company's sustainability journey, learnings for how to implement sustainability can be drawn. There was a clear change when the company understood how the actions of product development, on an operational level, are connected to company strategy and put in a context of a vision for a sustainable society. To have a corporate strategy, management support and high awareness in the company, are also highlighted as success factors for sustainability implementation by other researchers (e.g. Held et al., 2018). The fact that the company has been involved in technology projects with a clear sustainability target, such as resource efficiency of engines, parallel to the research projects summarized in this paper, has probably had a positive effect on that understanding and therefore on the implementation of the sustainability research. People involved in sustainabilityrelated technology development projects have been experienced as more positive to the implementation of SPD. The SPD has gradually increased the capabilities of the product design team so that they know when and how to implement sustainability in the early product innovation process and, therefore, the SPD has assisted in the implementation of the more sustainable technology - a winwin situation. The technology projects have also provided concrete sustainability targets which is an important aspect acccording to Alblas et al. (2014) for the management to be able to justify company investments of sustainability initiatives and to make progression.

For some reasons, and maybe because there was no close collaboration between academic researchers and industrial practitioners (Ahmad et al., 2018), the company did not apply any support tools and methods for SPD regularly in the product innovation process before this sustainability journey started. The maturity level was lower and the awareness, knowledge and management commitment to integrate and implement sustainability was not very strong. Furthermore, even if support tools existed they were too general and it was not possible to adapt them to the company-specific needs. In addition, these types of support tools all display shortcomings from a sustainable product development perspective as they fail to include a long-term perspective, which is needed in the development towards a sustainable society (Lozano, 2008). Future areas to explore for the company include how to make use of the digitalisation, sustainability and servitization trends using the knowledge and experiences gathered in the company so far (Isaksson et al., 2018). In addition, there is a need to improve SPD tools and their performances in combination of applying simulation-driven approaches, as suggested in Ahmad et al. (2018). Also it is required to get an even better understanding of the products' sustainability impact, improvement potentials and the importance of sustainability implementation in the product innovation process to be successful in sustainable product development (Short et al., 2012). 


\section{CONCLUSIONS}

The sustainability implementation journey at GKN Aerospace Engine System began over ten years ago, and demonstrates the importance of long-term university-industry collaboration. Even if this sustainability journey was not a planned process, learnings from implementing research in general and sustainability research in particular into product development can be found. Keyfactors, described below, are identified as applicable also in short-term collaborations for a faster implementation journey.

Common understanding and openness. The more the product design teams participated and engaged in the activities and surveys, the more was the learning and usefulness of the research outcome for them, which was seen already in the preventive phase. The company also allowed an openness which meant that the researchers could spend as much time as needed at the company doing interviews, workshops, collecting data etc., and the researchers, therefore were able to get a good understanding of the industrial situation and challenges. Specifically for sustainability research implementation was the importance of the continuous interactions, exercises, and regular presentations of the research results at the company that gave a good understanding in the product design team of what sustainability means, of the products' sustainability impact, of sustainability improvement potentials and of the current research being conducted. Based on this understanding it became an incentive to include sustainability in early decisions regarding technology and product development, which according to e.g., Chiu and Chu, 2012, can provide opportunities for enhancing the product competitiveness.

Customization and adaptability of tools and methods. Apart from previous research findings related to meet the desired characteristics of support tools (Ahmad et al., 2018), a customization of the support tools derived from the research to the company's specific problems is a key factor. This customization process, took place in the proactive phase at the company, should be led by the industrial partner to make it fit the current processes and tools at the same time as it is supported by the researcher to secure that the core of the support tool is not lost. This step-by-step process for tool delivery from research to practise, so called scaffolding, is important for sustainability research implementation as it helps individuals at the company to feel confident, which leads to a motivation for a change that is needed to include sustainability in a design project (Gould, 2018).

Receiver in industry and in-kind contribution. To implement sustainability research in product development, companies need to have a receiver that can activly participate in the research project. It is important to have at least one person disposing of time and having responsibility in the company, a person who also has the interest, the knowledge, the ability to receive and implement the research results, and get it in the system for complete implementation. For GKN the major influence on the transformation from preventative to systematic phase, was this person. As the understanding where and how to implement each tool or method can be difficult for an external person.

Long-term and continuous collaboration. Since sustainability might require large organisational changes on strategic, tactic and operational levels, it is a long-term journey. Continuous collaboration creates trust between people and it is important that the industry is involved from the beginning in the creation of the research questions, throughout the research and until the collection of results. For successful research implementation, it is important that the academic and industrial partners share the expectations of the outcome from the research. This became obvious in the research projects conducted with GKN, see Table 1, as the expectations were thoroughly discussed before each project.

Parallel projects regarding sustainability create a positive atmosphere to sustainability, supporting capability development, and offering a win-win situation for the projects. For example, a method development project can support the implementation of new sustainable technologies. A synergy effect is ocurring when the technology projects can provide concrete sustainability targets, which the management understand and thereby justify company investments of sustainability initiatives (Alblas et al. (2014).

It should be noted that these conclusions are based on SPD research projects, derived from a longitudinal case study that gives insights and learnings from a longer time perspective both in terms of general factors for implementing research but also specifically from implementing sustainability research in practice.

\section{ACKNOWLEDGMENTS}

Financial support from Sweden's Innovation Agency Vinnova and the Knowledge Foundation in Sweden is gratefully acknowledged. Sincere thanks to the industrial research partner GKN Aerospace Engine System AB, Sweden. 


\section{REFERENCES}

Agrawal, J.D. (2001), "University-to-industry knowledge transfer: literature review and unanswered questions", International Journal of Management Reviews, Vol. 3 No. 4, pp. 285-302. http://doi.org/d76vhs.

Ahlström, P. and Karlsson, C. (2009), Longitudinal field studies Researching Operations Management, Routledge, New York, pp. 196-235.

Ahmad, S., Wong, K.Y., Tseng, M.L. and Wong, W.P. (May 2018), “Sustainable product design and development: A review of tools, applications and research prospects (Article)", Resources, Conservation and Recycling, Vol. 132, pp. 49-61. http://doi.org/gdb3xf.

Alblas, A.A., Peters, K. and Wortmann, J.C. (2014), "Fuzzy sustainability incentives in new product development: An empirical exploration of sustainability challenges in manufacturing companies", International Journal of Operations and Production Management, Vol. 34 No. 4, pp. 513-545. http://doi.org/cxnj.

Avison, D., Lau, F., Myers, M. and Nielsen, P.A. (1999), “Action research”, Communications of the ACM, Vol. 42 No. 1, pp. 94-97. http://doi.org/c58gg5.

Beckmann, G., Gebhardt, N., Bahns, T. and Krause, D. (2016), “Approach to transfer methods for developing modular product families into practice", International Design Confernece - Design 2016, Dubrovnik - Croatia, May 16 - 19.

Bertoni, A., Dasari, S.K., Hallstedt, S. and Andersson, P. (2018), "Model-based decision support for value and sustainability assessment: applying machine learning in aerospace product development”, International Design Conference - Design 2018, Dubrovnik - Croatia, May 21-24. http://doi.org/gdmw27

Bertoni, M., Hallstedt, S. and Isaksson, O. (2015), "A model-based approach for sustainability and value assessment in the aerospace value chain", Journal of Advances in Mechanical Engineering, Special Issue on "Environmentally Conscious Technologies in Mechanical Engineering" http://doi.org/f3pnrf.

Blessing, L.T.M. and Chakrabarti, A. (2009), DRM, a Design Research Methodology, Springer Dordrecht Heidelberg, London New York. http://doi.org/dgbtm.

Borell-Damian, L. (2009), University-Industry Partnerships for Enhancing Knowledge Exchange, European University Association Publications 2009, Belgium. ISBN: 9789078997139.

Bovea, M.D. and Pérez-Belis, V. (2012), "A taxonomy of ecodesign tools for integrating environmental requirements into the product design process", Journal of Cleaner Production, Vol. 20, pp. 61-71. http://doi.org/dzxd5d.

Broman, G.I. and Robèrt, K.-H. (2017), “A Framework for Strategic Sustainable Development”, Journal of Cleaner Production, Vol. 140 No. 1, pp. 17-31. http://doi.org/gb2fhp.

Buchert, T., Kaluza, A., Halstenberg, F.A., Lindow, K., Hayka, H. and Stark, R. (2014), "Enabling product development engineers to select and combine methods for sustainable design", Procedia CIRP 2014, 15, pp. 413-418. http://doi.org/cxpm.

Coughlan, P. and Coghlan, D. (2009), “Action research”, In: C. Karlsson, (Ed.), Researching operations management, 1st ed., Routledge, New York. http://doi.org/cxpn

Chiu, M.-C. and Chu, C.-H. (2012), "Review of sustainable product design from life cycle perspectives", Int. J. Precis. Eng. Manuf, Vol. 13, pp. 1259-1272. http://doi.org/cxpp.

Choi, J.K., Nies, L.F. and Ramani, K. (2008), "A framework for the integration of environmental and business aspects toward sustainable product development”, Journal of Engineering Design, Vol. 19 No. 5, pp. 431-446. October 2008, http://doi.org/cq9wwk.

Dunphy, D.C., Griffiths, A. and Benn, S. (2007), Organizational Change for Corporate Sustainability: a Guide for Leaders and Change Agents of the Future, second ed., Routledge, London; New York. http://doi.org/cxpq.

Gagnon, B., Leduc, R. and Savard, L. (2012), "From a conventional to a sustainable engineering design process: different shades of sustainability", Journal of Engineering Design, Vol. 23 No. 1, pp. 49-74. http://doi.org/ffswcw.

Gaziulusoy, Aİ, Boyle, C. and McDowall, R. (2013), "System innovation for sustainability: a systemic double-flow scenario method for companies", Journal of Cleaner Production, Vol. 45, pp. 104-116. http://doi.org/cxps.

Hallstedt, S. (2017), "Sustainability Criteria and Sustainability Compliance Index for Decision Support in Product Development", Journal of Cleaner Production, Vol. 140, pp. 251-266. http://doi.org/f3pxzg.

Hallstedt, S. and Isaksson, O. (2017), "Material criticality assessment in early phases of sustainable product development”, Journal of Cleaner Production, Vol. 161, pp. 40-52. http://doi.org/gbv2jz.

Hallstedt, S., Ny, H., Robèrt, K.-H. and Broman, G. (2010), "An approach to assessing sustainability integration in strategic decision systems for product development”, Journal of Cleaner Production, Vol. 18, pp. 703-712. http://doi.org/dr7ss8.

Hallstedt, S.I., Thompson, A.W. and Lindahl, P. (15 July 2013a), "Key elements for implementing a strategic sustainability perspective in the product innovation process", Journal of Cleaner Production, Vol. 51, pp. 277 288. http://doi.org/f23hm7.

Hallstedt, S., Thompson, A., Isaksson, O., Larsson, T. and Ny, H. (2013b), “A decision support approach for modeling sustainability consequences in an aerospace value chain”, Proceedings of ASME, 18th Design for Manufacturing and the Life Cycle Conference (DFMLC), August 4-7 2013, Portland, USA. http://doi.org/cxpt

Hallstedt, S., Bertoni, M. and Isaksson, O. (2015), “Assessing sustainability and value of manufacturing processes: a case in the aerospace industry”, Journal of Cleaner Production, Vol. 108, pp. 169-182. http://doi.org/f3pz7z. 
Hallstedt, S. and Pigosso, D. (2017), "Sustainability integration in a technology readiness assessment framework", Proceedings of the 21st International Conference on Engineering Design (ICED 17), Vol 5, Vancouver, Canada, 21-25 August. http://doi.org/cxpv

Hassan, M.F., Saman, M.Z.M., Mahmood, S., Nor, N.H.M. and Rahman, M.N.A.J. (January 2017), "Sustainability assessment methodology in product design: A review and directions for future research", Journal Teknologi, Vol. 79 No. 1, pp. 37-44. http://doi.org/cxpw.

Held, M., Weidmann, D., Kammerl, D., Hollauer, C., Mörtl, M., Omer, M. and Lindemann, U. (10 September 2018), "Current challenges for sustainable product development in the German automotive sector: A survey based status assessment”, Journal of Cleaner Production, Vol. 195, pp. 869-889. http://doi.org/gd2pt9.

Hsieh, H.F. and Shannon, S.E. (2005), "Three Approaches to Qualitative Content Analysis”, Qualitative Health Research, Vol. 15 No. 9, pp. 1277-1288. http://doi.org/bhp2s9.

Intergovernmental Panel on Climate Change -IPCC (2018), Global warming of $1,5^{\circ} \mathrm{C}$.

Isaksson, O., Bertoni, M., Hallstedt, S. and Lavesson, N. (2015), "Model Based Decision Support for Value and Sustainability in Product Development", Proceedings of the 20th Int. Conference on Engineering Design (ICED), Milan, Italy, July 27-30.

Isaksson, O., Hallstedt, I.S. and Rönnbäck, ÖA (2018), "Digitalisation, sustainability and servitisation: Consequences on product development capabilities in manufacturing firms", International Design Conference - Norddesign. Linköping, Sweden, August 14-17.

Kara, S., Ibbotson, S. and Kayis, B. (2014), "Sustainable product development in practice: An international survey", J. of Manufacturing Technology Management, Vol. 25 No. 6, pp. 848-872. http://doi.org/cxpz.

Kishawy, H.A., Hegab, H. and Saad, E. (10 October 2018), "Design for sustainable manufacturing: Approach, implementation, and assessment", Sustainability, Vol. 10 No. 10, Article number 3604 http://doi.org/cxp2

Lermen, F.H., Echeveste, M.E., Peralta, C.B., Sonego, M. and Marcon, A. (1 August 2018), “A framework for selecting lean practices in sustainable product development: The case study of a Brazilian agroindustry", Journal of Cleaner Production, Vol. 191, pp. 261-272. http://doi.org/gdvf5c.

Lozano, R. (2008), "Envisioning sustainability three-dimensionally", Journal of Cleaner Production, Vol. 16 No. 17, pp. 1838-1846. http://doi.org/c97wrt.

Mourtzis, D., Papatheodorou, A.-M. and Fotia, S. (1 December 2018), "Development of a key performance indicator assessment methodology and software tool for product-service system evaluation and decision-making support", J. of Computing and Information Science in Eng., Vol. 18 No. 4), http://doi.org/cxp3.

O’Donoghue, T. and Punch, K. (Eds.) (2003), Qualitative educational research in action: Doing and reflecting, Routledge. https://doi.org/10.4324/9780203506301.

Rodrigues, V.P., Pigosso, D.C.A. and McAloone, T.C. (10 July 2017), "Measuring the implementation of ecodesign management practices: A review and consolidation of process-oriented performance indicators", Journal of Cleaner Production, Vol. 156, pp. 293-309. http://doi.org/gbkddp.

Rodrigues, V.P., Pigosso, D.C.A., Andersen, J.W. and McAloone, T.C. (14 June 2018), "Evaluating the potential business benefits of ecodesign implementation: A logic model approach”, Sustainability (Switzerland), Vol. 10 No. 6), Article number 2011. http://doi.org/gd762d.

Schulte, J. and Hallstedt, S. (2017), "Challenges and preconditions to build capabilities for sustainable product design", Proceedings of the 21st International Conference on Engineering Design (ICED 17), Vancouver, Canada, 21-25 August. Vol 1. http://doi.org/gd8mqp

Schulte, J. and Hallstedt, S. (2018a), "Company Risk Management in Light of the Sustainability Transition", Sustainability, Vol. 10 No. 11, pp. 4137. http://doi.org/cxp5.

Schulte, J. and Hallstedt, S. (2018b), "Self-Assessment Method for Sustainability Implementation in Product Innovation", Sustainability, Vol. 10 No. 12, pp. 4336. http://doi.org/cxp6.

Short, T., Lee-Mortimer, A., Luttropp, C. and Johansson, G. (December 2012), "Manufacturing, sustainability, ecodesign and risk: Lessons learned from a study of Swedish and English companies", Journal of Cleaner Production, Vol. 37, pp. 342-352. http://doi.org/f23r56.

Steffen, W., Richardson, K., Rockstrom, J., Cornell, S.E., Fetzer, I., Bennett, E.M., Biggs, R., Carpenter, S.R., de Vries, W., de Wit, C.A., Folke, C., Gerten, D., Heinke, J., Mace, G.M., Persson, L.M., Ramanathan, V., Reyers, B. and Sorlin, S. (2015), "Planetary boundaries: Guiding human development on a changing planet", Science, Vol. 347 No. 6223, pp. 1259855-1259855. http://doi.org/f3m6n9.

Carolina, V. and Sophie, H. (2018), "Sustainability product portfolio - a review”, European Journal of Sustainable Development, http://doi.org/gd8zkn.

Wallace, K. (2011), “Transferring Design Methods into Practice”, In: H Birkhofer, (Ed.), The Future of Design Methodology, Springer, London, pp. 239-248. http://doi.org/cwbm8s.

Wallin, J., Isaksson, O., Larsson, A. and Elfström, B.O. (2014), "Bridging the Gap Between University and Industry: Three Mechanisms for Innovation Efficiency", International Journal of Innovation and Technology Management, Vol. 11 No. 1, pp. 1440005. http://doi.org/f3nswv.

Watz, M. and Hallstedt, I.S. (2018), "Sustainability in product requirements. International Design Conference", Proceedings of Design Conference, Dubrovnik - Croatia, May 21-24, 2018. http://doi.org/gd8xw4 